a radical change has taken place in this respect the position is bound to be that the industries as a whole will remain unable to obtain the full benefit of the results of scientific investigation." The scale upon which research is organized, and even its extent in Great Britain, still compare unfavourably with that in some of its competitors, and it cannot yet be contended that with all the advances of the past twenty-five years the value of scientific research and its contribution to industrial progress or national welfare is generally appreciated either by the general public or by the Government.

The increased attention which is now being given to the general structure of the organization of research in Great Britain itself shows that the work of education has progressed. The twenty-five years' work of the Department will be considered not by itself but in relation to the research proceeding in industry, at the universities, and under more direct Government auspices, such as through the Agricultural Research Council or the Medical Research Council. If the expansion still required for the full service of the needs of individual industries or of national needs is to be secured, more than additional financial resources is required. There is still need for close co-ordination of exist. ing effort, and for the re-distribution of available resources, whether of personnel or equipment. The lack of proportion between scientific advance in different fields is a handicap which requires correction and involves further attention to our educational system, possibly by more fundamental methods than the distribution of grants to students or research workers. Progress here depends on the education both of public opinion and of the administrator. We may well hope that, in glancing over the twenty-five years' work of the Department of Scientific and Industrial Research, scientific workers may be led to take a further part in that task of education and give firmer and more united support to the elaboration of a national policy and programme of scientific and industrial research which will serve the nation's changing and growing needs, whether in peace or war, on a more adequate scale.

\title{
SCIENCE IN THE ROYAL ACADEMY, I940
}

\section{By Lieut. W. E. Swinton, R.N.V.R.}

$\mathrm{T}$ HE one hundred and seventy-second exhibition of the Royal Academy of Arts, which opened on May 6, is a typical "Royal Academy". That is to say, it is conservative and consists of the same kind of interesting, promising, or sometimes even satisfying works largely by the usual artists. Its subjects for the most part are retrospective, concerned with the personalities and events of the past rather than reflecting the tendencies and affairs of the present. It is therefore natural that the general tendency of the works is to portray the splendours of the seasons and those rural and coastal charms accessible to the country cottage rather than the stirring, if unpleasant, realities that confront us now. Artistic licence, however, like that of the poets, stipulates no adherence to the apparently stupendous events of the day, a fact which may explain why art is more enduring than the news-sheet.

There are, of course, a few works devoted to the more spectacular events of the last few months. Of these, pride of place goes to Norman Wilkinson's "River Plate Action", an inspiring representation based on the account given by Captain Woodhouse, R.N., and the same artist's "Air Battle, December 18th, 1939", painted from a description given by the leader of the formation. The Altmark incident is recalled by "The Stranded Prison-ship", by
Charles Gere, R.A. "The Convoy and her Guard", by A. J. W. Burgess; "Suburbia, 1939", by C. R. W. Nevinson, A.R.A.; and "Retribution", the end of a U-boat, by Arthur Burgess, bear testimony to the less spectacular necessities of these times.

So far as strictly scientific activities are concerned, this exhibition is no more lavish than its predecessors. If the highways and byways of scientific endeavour have any artistic stimuli, it must be admitted that the results do not pass the strait gate of Burlington House. Of the seventeen hundred works now shown, only about ninety can be said to be even incidentally of scientific interest, and that is taking both science and the subjects of the pictures at a very wide estimate.

As usual, the botanists and the geologists have nearly all the spoils, largely because flowers are amongst the most convenient themes for both indoor and outdoor painting, and because, on the other hand, landscape painters of even the most modern school can scarcely avoid some hint of the geological background.

Agriculture, as in last year's exhibition, has one of the best pictures of the year, by that habitual author of 'best pictures', Dame Laura Knight. It is entitled "January, 1940", and depicts a landgirl at work in wintry surroundings. 
Archæology is represented by Charles Oppenheimer's large and pleasing "Roman Wall, Northumberland", and by Mr. W. P. Robins's more topical "The Saxon Ship at Sutton Hoo". There is a score of castles from many parts of this and other countries, and in various stages of disrepair, which may also attract the antiquary, but space does not permit their catalogue here.

For the anthropologist there is a small number of pictures of distinguished artistry and origin. Negroes, Chinese and Gypsies are the favourite subjects: and of these Laura Knight's "The Gypsy" (purchased under the Chantrey Bequest); Sir John Lavery's "Gypsies in Ireland", a work painted some years ago; and the continuation of Mr. Gerald Kelly's charming Burmese studies must be mentioned.

For the botanist, or perhaps more accurately the flower-fancier, the Academy must be a delight. Art does more than memory, for it gives us roses all the year round. Here, there are roses in plenty, and lilies, pinks, cornflowers, cinerarias and tulips, "Spring Flowers", "June Flowers", "Summer Flowers", from anemones to zinnias. Trees there are, too, trees casting their cool and leafy shade, trees burdened with snow, and trees brilliant with blossom. Attractive and somewhat unexpected examples of the latter group are Mr. George Belcher's "Tugley Farm", with its contrast of summer sun and shade, and the luxuriant foliage of Mr. A. J. Munnings' "Drifting", a large and colourful canvas with a canoe on the limpid waters of a tree-shaded stream.

Geologists with imagination have an even richer field this year in which to exercise their fancy. Scottish scenery vies with the English moorland for pride of place, with coastal attractions of the south and the staccato splendour of the Alps following on; a variety which is happily knit by the versatility of Oliver Hall, R.A., who shows typical highland features in his "Bridge in Inverness-shire", the characters of its English counterpart in "Rothbury Moors, Northumberland", and supplies the continental contrast of a recently dissected plateau in "Ronda, Spain". A somewhat sharper contrast in topography is seen in the gently rounded features of the old landscape of "A Fifeshire Farm", by R. W. Stewart, and the jagged boldness of the "Dents du Midi" of the late Melton Fisher. "Winter in a Cotswold Village" (A. G. James) and "Winter in Perthshire" (McIntosh Patrick) are gentler variations of the same theme, to be compared with the sterner work of snow and ice visible in "Zermatt" by Mrs. Elwell. For a complete contrast there is the attractive panorama by Charles Gere, R.A., entitled "The Tidal Severn", with its well-displayed meanders. Typical cliff and coastal scenery, which is perhaps even more attractive to the field geologist, is supplied by Gerald Kelly in his "Golfo Tigulio, II"; in "Swanage", by R. R. Gill; and especially in "The Mewstone: Entrance to Dartmouth from Seaward", by Charles Pears.

Applied geology is represented only by "The Derelict", a tempera painting by Mr. Harry Allen, which shows an old quarry and its abandoned crusher.

Mineralogy is almost entirely unrepresented. Hitherto it has been safe to rely upon the jewelled richness of Gerald Brockhurst's portraits, but Mr. Brockhurst is one of many academicians who have not exhibited this year. The meteorologists, too, must take what they can from a very few landscapes, of which Sir A. Brown's "A Passing Shower", with its thundery sky, and Bertram Priestman's "Storm Clouds, North Wales" call for special mention.

The important and attractive field of industry and engineering is unexpectedly neglected, although Alan Blyth's two topical pictures "Building an R.A.F. Aerodrome" and "Evening at an R.A.F. Aerodrome" do something to alleviate the deficiency.

The number of pictures of zoological interest is also smaller this year. Mr. Munnings' studies of racehorses as usual command attention, and Dame Laura Knight contributes a delightful scene of a quieter kind in her "Suffolk Mare and Foal". Miss Jessie Hodge also has a pleasant study of a swan with its chicks in "All Aboard!". Phillip Connard's "Pelicans", which has been bought for the Academy under the Chantrey Bequest, is of interest, as is Mrs. Daisy Smith's "Amherst's Pheasant". The farmyard aspect is supplied by "Gloucester Spots at Abnash", by J. A. Colquhoun Morrison.

"The Aviary", by James Fitton, is suggestive of a zoo ; while "Painting the Air Balloon", a tempera by Ernest Dinkel, reveals a glimpse of the museum workshop.

There are several items of architectural interest for scientists: "Scaffolding at Winchester College, 1938"; "Canterbury Quad, Christchurch, Oxford"; "Hertford College Bridge, Oxford"; "The University of London, Interior of Great Hall"; "Goldsmiths' Library, University of London"; and an interesting model of the new University buildings in Bloomsbury by Charles Holden. There are also drawings and plans of the Courtauld Science and Art Block of Felsted School, and of the Garden Court Wing of the British Medical Association.

Portraits or statuary of scientific and university men are not numerous, but the few are worthy of attention. Pre-eminent among them is the splendid life-size painting of the late Lord Crawford by James Gunn, one of the best pictures in the 
exhibition. Augustus John celebrates his return with a fine portrait of the Hon. Vincent Massey; and Mr. R. G. Eves, R.A., has deposited as his diploma work his portrait of Sir Joseph Barcroft. The Rev. E. Schomberg, Master of Charterhouse (Ronald Gray), the late Dr. H. R. Rathbone (L. Campbell Taylor), and Sir Herbert Baker (A. K. Lawrence, R.A.) are other notable portraits. Physicians are well represented by Sir Robert Hutchison (James Gunn), the late Prof. Edward Mapother (A. R. Thomson, A.R.A.), and Dr. E. B. Gunson (James B. Manson). There is also a charming miniature of Dr. Cyril Horsford by his daughter.

Museum men will be pleased to see the miniature of Dr. Charles ffoulkes by Dorothy Garratt, and the sanguine by Robert Swan of Mr. F. W. Troup. Miss Helen Campbell has done a chalk study of Sir Dennison Ross.

Amongst the sculpture there must be mentioned the bronze bust of Lord Cadman (Donald Gilbert), the bronze bust of Sir David Milne-Watson (Eric Schilsky), and the model of a bronze memorial to Sir Archibald Denny (L. S. Merrifield). Miss Barbara Tribe has done an excellent bust of that distinguished soldier and master of Peterhouse, Lord Birdwood. Mr. Bertram Pegram exhibits a bust of Sir Daniel Lleufer Thomas, a welcome testimony to services to the University and National Museum of Wales, and Mrs. BingguelyLejeune has a bronze relief of that great patron of the sciences, Lord Nuffield.

\section{DISTRIBUTION OF MARINE ORGANISMS}

\begin{abstract}
$\mathrm{A}^{\mathrm{T}}$ $\mathrm{T}$ the general meeting of the Linnean Society of London on April 25, a discussion regarding the extent to which the distribution of marine organisms can be explained by, and is dependent on, the hydrographical conditions present in the great oceans was opened by Lieut.-Colonel R. B. Seymour Sewell.
\end{abstract}

After dealing with the main categories of marine organisms-plankton, nekton, and benthos-and defining the various types of plankton, Col. Sewell considered the ancient Tethys Sea and the effect of its subsequent closure on the distribution of corals. The view has often been advanced that species found to be limited to-day to the North Atlantic and northern part of the Indian Ocean are relics from this early Tertiary sea; but recent investigations have so greatly increased the number of these species that this explanation is unlikely. A study of the ancient group of Crinoids provides an alternative explanation, and suggests that, while some species have reached the Atlantic and Arctic Oceans from the centre of origin in the region of the Malay Archipelago through the Tethys Sea, others have been dispersed along lines which correspond closely with the surface and deep-water currents of the present day.

There can be no doubt that the character and direction of flow of marine currents have had a profound influence on the fauna and flora of different regions, and are sufficient to account for the frequency with which species are found to be cosmopolitan in their habitat. Further, the convergence zones set up in regions where the different current systems abut upon each other may provide temperature barriers across which only the most tolerant species are able to pass, and thus give us sharp boundary lines between two types of fauna or flora.

Detailed studies of various groups of animals and plants within the limits of a single ocean have produced an important body of evidence as to the correlation between the distribution of the organisms and the presence of water of a particular origin, as well as the direction and extent of flow of this water. This has been well shown in investigations on both phyto- and zoo-plankton of the North Atlantic, as well as on the diatoms of the Southern Ocean, and evidence is also accumulating that benthonic organisms may be affected in much the same way, as shown by recent work on seaurchins, barnacles and sponges.

A study of the various zoogeographical regions which have been delimited as the result of work on the surface plankton reveals that these correspond fairly closely with the surface currents, and that the main line of dispersal for such plankton runs from east to west. A systematic study of the weed-haunting Harpacticid Copepods or of the surface-living Calanoids suggests that a very large percentage of the species of these crustaceans must have originated in the region of the Malay Archipelago, and that the farther we get away from this region the smaller is the number of Indo-Pacific species to be found, as might be expected if their dispersal is due to the surface currents. Similar evidence has been provided by the distribution of other groups of animals and of the littoral algæ.

In regard to the deeper levels, a study of the distribution of the meso-planktonic Calanoids again shows a distinct correlation with the general trend of the mid-water and deep currents. In this group the centre of origin appears to have been largely 